\title{
Thinking Inside the Box: A Blueprint for Green New Deal Industrial Mobilization and Strategy for Human Capital Repurposing
}

\author{
Timothy Nerenz \\ The Graduate School, University of Maryland Global Campus Europe, Kaiserslautern, Germany \\ Email: timothy.nerenz@faculty.umuc.edu
}

How to cite this paper: Nerenz, T. (2019) Thinking Inside the Box: A Blueprint for Green New Deal Industrial Mobilization and Strategy for Human Capital Repurposing. Journal of Human Resource and Sustainability Studies, 7, 368-387. https://doi.org/10.4236/jhrss.2019.73024

Received: May 8, 2019

Accepted: July 30, 2019

Published: August 2, 2019

Copyright () 2019 by author(s) and Scientific Research Publishing Inc. This work is licensed under the Creative Commons Attribution International License (CC BY 4.0).

http://creativecommons.org/licenses/by/4.0/

\begin{abstract}
The American "Green New Deal" (GND) is a controversial public policy initiative described by advocates as the "millennial generation's World War II" that seeks to ban carbon-based and nuclear energy in order to avoid a predicted Climate Change apocalypse. Proponents of GND have thusfar failed to offer a substantive proposal for the industrial mobilization necessary to win their war on carbon, and this paper attempts to fill that void with development of a rough-order estimate of $\$ 52$ trillion in new industrial output required to replace combustion-powered infrastructure. Drawing from World War II industrial mobilization as its template for urgent human resourcing, the paper proposes that deconstructing the current post-secondary education sector by $65 \%$ and repurposing its currently misappropriated human capital to industrial mobilization provide the only apparent available cohort of requisite size and intellectual acuity to achieve GND goal realization in 20 years. The paper is intended to provide a rational basis upon which advocates and proponents alike can engage in a debate that includes GND feasibility and its broader implications for re-industrialization and sector re-orientation of the US economy during the working lifetimes of millennials.
\end{abstract}

\section{Keywords}

Climate Change, Green New Deal, Millennials, Industrial Capacity, Human Capital, Post-Secondary

\section{Introduction}

In January of 2019 New York Congresswoman Alexandria Ocasio-Cortez announced an ambitious public policy agenda called the Green New Deal (GND) to combat the existential threat of Climate Change, and described it as the mil- 
lennial generation's "World War II" [1].

The central goal of GND is to eliminate carbon-based and nuclear energy by 2030, the date proffered by Climate Change activists as the point of no return for reversing global warming and avoiding planetary extinction [2]. For purposes of argument, the paper accepts without examination this apocalyptic assertion, which by implication demands the assumption that implementation of GND should be the nation's top public policy priority.

GND is overwhelmingly supported by millennials [3] despite the absence of any notional plan for GND implementation or meaningful understanding of the effort that will be required of them to win their war on carbon. Opponents of GND largely dismiss the initiative out-of-hand, with equally insufficient bases for determinations of unfeasibility. What is missing from both sides of the current political debate is a rational basis upon which the predicate question of GND should be approached; namely the question of what it would take to actually implement it within a meaningful timeframe.

The paper begins with historical context-an examination of key characteristics of the World War II industrial mobilization from which GND draws its metaphorical inspiration. It then develops a rough-order-of-magnitude estimate of new industrial output-a $\$ 52$ trillion blueprint-that GND requires to replace existing carbon-combustion capital infrastructure with electrified equivalents and the power-sourcing to operate them. Major items listed include:

- 1.6 million $5 \mathrm{~kW}$ wind turbines;

- 48,676 miles of new high-speed rail and the passenger trains that will replace air travel;

- electrification of 137,000 route miles of existing freight rail;

- 41,000 electric locomotives;

- 252 million electric cars, trucks, buses, and motorcycles;

- 10 million units of agricultural machinery-tractors, combines, etc.;

- construction of additional new industrial facilities to provide the required manufacturing capacity.

Drawing from the WWII mobilization template, the paper profiles the necessary cohort of human capital in sufficient numbers and intellectual profile to achieve GND mobilization at this scale within the working lifetimes of the oldest millennials. It identifies the only apparent readily-available and suitable pool-those currently misappropriated to the post-secondary education sector. The paper proposes a GND feasible victory strategy made up of five core elements:

1) doubling of the current US industrial base-facilities and equipment;

2) deconstruction of $65 \%$ of post-secondary education;

3) repurposing its excess occupants (24 million) to GND industrial mobilization output;

4) utilization of proven mass-scale psychometric modeling for immediate occupational matching;

5) aggressive de-regulation of the industrial, agriculture, and transportation sectors. 
It will suggest that a 20 -year horizon for GND may be within the realm of debatable possibility, but only if human capital currently sequestered in post-secondary education is immediately repurposed to significantly de-regulated industrial sectors of the American economy, essentially re-creating the conditions in which the millennials' great-grandparents were able to achieve their mobilization victory in World War II.

\section{Methodology}

The sources of statistical data used in the development of analysis are found in the public domain and retrieved from digital databases using commercial search engine applications (Google, Bing) and searches of University of Maryland Global Campus library resources. It draws upon the author's personal knowledge of specific key industries gained over four decades as a business executive in key industrial sectors, and the author's second-career experience in course development and teaching at the graduate level (MBA) in the areas of strategy, organizational development, major change leadership, risk management, operations management, and merger \& acquisitions.

Categories of sources referenced are:

- Primary source documents published by US government agencies-e.g. Census Bureau, BLS, and Department of Education;

- Journal articles, historical narratives, trade publications, and opinion survey research;

- Secondary source digital documents which cite primary source documents-publications, periodicals, web-based information-sharing sites, periodicals. opinion pieces;

- Secondary source digital documents which report un-cited data or restate generally accepted principles.

The frameworks applied in the qualitative analysis are multi-disciplinary, drawing from scholarship, research, and practice in the fields of business administration, economics, marketing, psychology, social psychology, industrial psychology, industrial engineering, and organizational behavior. Theory building is both inductive, building generalized theories and hypotheses from evidence and observation, and abductive, proposing probable new theory and hypothesis where no clear linkage between the evidence and observation to known theory exists.

In determining a gross estimate for GND infrastructure, several assumptions and proxies were required in the absence of a detailed plan put forth by its advocates. Proxy values and assumptions used in calculating GND costs for sizing purposes are as follows:

1) Cost for wind energy conversion is based on a per-kW rule of thumb from American Wind Energy Association publications for feasibility studies;

2) Cost for HSR is based on the per-mile cost-at complete estimates from the California High Speed Rail Authority for the HSR project in process connecting 
Los Angeles to San Francisco;

3) Miles of HSR needed to replace commercial aviation are developed by proxy from the existing Interstate highway system, which connects to cities where over $90 \%$ of commercial flights originate;

4) Cost for HSR rolling stock is based on planning cost "rules of thumb" developed for several European and Asian HSR proposals;

5) Cost for agricultural equipment replacement is based on average costs for existing diesel equipment as advertised on dealership web sites;

6) Cost for freight rail is based on the average per-mile planning estimates used in feasibility studies filed with planning commissions in Texas and New Jersey (rural and urban). Locomotive costs are industry estimates;

7) Costs for replacing combustion-engine on-road vehicles with electrics is based on total vehicles with an author-selected reasonable estimate of per-vehicle cost. No breakdown by vehicle type was attempted;

8) Gross capital formation of the industrial base is a crude estimate taking the current ratio of GCF to GDP in total for all corporations and applying it to the industrial sector GDP with an author-selected adjustment factor.

Estimates of materiel cost and human resources are presented as gross estimates, developed only for purposes of comparisons to World War II mobilization and to facilitate debate over the broad scope of economic sector transformations necessary to achieve the goals proposed in GND. They are not represented to be detailed and verifiable computations from which actionable plans could be recommended without considerable additional study and verification.

\section{Analysis and Discussion}

The Green New Deal has been labeled the millennial generation's World War II. And so this section will begin with a review of the historical record of that achievement, identifying the key characteristics that enabled mobilization on a national scale to be successful. It will then develop a rough-order-of magnitude estimate of GND infrastructure materiel production required to compare the relative order of magnitude of GND scale to its WWII inspiration. The next subsections will focus on human capital repurposing to achieve industrial output at scale required to support GND implementation and identify the intellectual profile match between 1940's industrial facility workforce and current post-secondary education sector cohorts. It concludes with an examination of the necessary deconstruction of post-secondary and the impact that sector re-assignment to industrial production will have on millennial earnings and career prospects for future generations in a re-industrialized and carbon-free economy.

\section{Wartime Mobilization in the 1940s}

Contingency planning for wartime mobilization began in the years immediately after the first world war, when the difficulties of raising and equipping a modern army of several million men on short notice became obvious [4]. Two broad societal trends converged in the inter-war years: 1) the progressive move- 
ment and its notion of professional management of public policy, and 2) the development of the mass-production industrial model and the transition from an agricultural to an industrial economy and the need for scientific approaches to the management of firms.

Significant advances in scholarship and research in the interwar period created new disciplines and specialized fields of study, most notably organizational behavior, industrial psychology, industrial engineering human factors engineering, and mass-scale business administration/management. Throughout the 1920s, 1930's and 1940's, foundational research in these disciplines developed frameworks for scaled occupational specialization and systematic measurement, assessment, and matching of applicant characteristics-IQ and its variants, learning style, aptitude, personality profile, physical ability, etc.-tools to match applicants to requirements of jobs and roles within the firm [5].

In parallel, the nation's war colleges were developing schemes for systematic training, education, and leadership development in the uniformed services [4] and as new technologies were developed with war-fighting application in both the private and public sector, the incorporation of $\mathrm{R} \& \mathrm{D}$ and procurement planning into the military sciences, enabled military planners to create feasible mobilization scenarios in advance for multiple contingencies. By 1940, much of the groundwork had been laid to allow for rapid mobilization on a massive scale to be executed successfully on relatively short notice. New commands and directorates in the War Department had been established to create fast-track systems and procedures for budgeting, managing contracts, and disbursing funds [4].

Three other significant conditions of that period should be noted: 1) In 1940, unemployment stood at $17.9 \%, 2$ ) nearly $20 \%$ of available industrial capacity-physical plant and equipment stood idle, and 3) 8 million women-homemakers never before in the labor force-were available and eager to mobilize.

Americans of that time possessed a work ethic that is hard for us to imagine today and had just suffered through a decade of the hardest times imaginable in the Great Depression and were well acquainted with sacrifice. By 1944, the consumption of resources by the war effort had led to critical shortages and rationing of goods and foodstuffs [4] and the nation soldiered on for two additional years under severe rationing restrictions undeterred. The necessity of winning the war was the unquestioned national top priority, and all resources-capital, human, material-needed to accomplish that goal was allocated to it. Items 2-n on the priority list accepted whatever remaining resources were rationed to their purposes. War-time industrial mobilization began in 1941, peaked in 1943, and continued into 1945. During the peak years of 1942-1944, factories making critical war material were running full-out 7 days per week, two shifts per day. The M-F shifts were 12 hours, Saturdays were 10 and Sundays 8, allowing time on the weekends for machinery and equipment maintenance [4]. Many worked double shifts to overcome the shortage of manpower created by the increasing buildup of the uniformed military. Few of us can imagine the commitment required to put in two years of 78 hour weeks of physical labor with only religious 
holidays off. Nearly $1 / 3$ of those who labored in the factories were women, many with husbands and sons off fighting and dying on foreign soil. Such was the strength of belief in the cause.

The entry of the United States into the war tipped the balance of industrial output from the Axis powers to the Allied powers and provided the decisive advantage that defeated Germany, Japan, and Italy and liberated the nations they had conquered virtually uncontested and occupied in the first half of the war. The Axis powers' military might and aggressive strategies delivered early victories, but that changed when the industrial capacity created by American capitalists and the engaged blue-collar workforce was enlisted in the war effort. While the quote is disputed and attribution has not been established, the mythical story of a German tank commander's lament that "one Tiger is equal to four Shermans; the problem is the Americans have five" sums up the strategic advantage of industrial output over specific platform superiority [6] that wartime mobilization provided to the Allies when America entered the war.

The scope of industrial mobilization is during the four years 1941 to 1945 has been unmatched since anywhere in the world. Some key metrics provide a sense of proportion [4].

- 600,000 private industrial firms shifted from civilian to military production;

- $\$ 1.9$ trillion in 2018 dollars spent on the production of machinery, munitions, and construction;

- 24 million employed in industrial war production/8 million of them female;

- $50 \%$ of the civilian workforce transitioned to war-time production;

- $20 \%$ increase in the civilian labor force from 55 million to 65 million 1940-1945;

- Unemployment dropped from 9.4 million to 670,000 1940-1945;

- 330,000 aircraft produced;

- 122,000 tanks produced;

- 1200 large ships produced; 2700 Liberty Ships (cargo) produced;

- 2.1 million tonnes of coal consumed;

- 369 million tonnes of iron consumed;

- 833 million tonnes of crude oil consumed.

The magnitude of the achievement of this generation cannot be overstated, and when we consider that this commitment and sacrifice was entirely voluntary; they earned the label "the Greatest Generation" many times over. The industrial mobilization of 24 million civilians and standing up of an army numbering over 5 million in just three years represents the largest industrial psychology experiment in history. Years of scientific studies developing correlations between cognitive testing and specific occupational performance were proven in practical application on a massive scale, as measurements of intelligence, learning agility, absorption and assimilation rates of information, and other elements of what is called collectively aptitude testing directed assignment to roles in both military and civilian mobilization staffing.

Intellectual Profile of WWII Mobilization Workforce

Predictive psychometric testing vehicles like the Wonderlic test [7] were de- 
veloped in the 1930s and utilized with great effect in the WWII mobilization of the 1940s. The processes, techniques, and practices of matching occupational demand bell curves with candidate supply curves which optimized the performance of individuals and teams in goal attainment were developed of necessity-literally a matter of life or death.

A condition of the national circumstance in 1940 that is rarely mentioned or fully appreciated is that at that time, the proportion of Americans with a college degree was $4.6 \%$ [8]. $4.6 \%$ degree density provided the nation with an adequate supply of doctors, lawyers, scientists, engineers, teachers, scholars, managers, psychologists, social workers, accountants, administrators, fine arts practitioners, business leaders, professors, philosophers, researchers, and other professionals in American society. In the decades that followed, the proportion of Americans with college degrees has risen sharply and is now over 35\% [8] but at the time of mobilization, a college education was a rare commodity.

The limited numbers of Americans enrolled in post-secondary education in 1940 made available a large wartime mobilization cohort of above average intelligence-a workforce supplying vision, strategic leadership, critical thinking skills, agile organizational thinking, and innovative practices grounded upon sound social science and the established body of scholarship developed over decades of research.

A 2015 article entitled "Manpower Planning in an Industrial Firm" [9] contains a photocopy of a 1940 factory survey record that shows $70 \%$ of the workforce posted Wonderlic scores higher than the current national average, with $30 \%$ above the 110 IQ equivalent. Another original document from the records of a 1963 factory displayed an identical above-average profile in histogram form [9]. The mobilization for World War II did more than win a war; it created the industrial base and the intelligent human capital cohort that propelled the US economy to undisputed world dominance and increasing prosperity for nearly three decades after the war itself was over.

The can-do legacy of WWII mobilization has carried forward into 21st century industrial production in the United States, where the firms who have survived the sea-changes of globalization and technology rely on agile manufacturing, self-directed teams, statistical process control, LEAN concepts, six-sigma, continuous, and other participative management themes to create and maintain sustainable competitive advantage. Many of these methods were first developed by urgent necessity as new practices were needed to achieve output and throughput increases in compressed timeframes.

\section{Mobilization for Green New Deal}

The 2019 Congressional resolution proposing the GND does not provide an estimate of costs to accomplish it, but it contains a list of broad goals [10] sufficient to produce some rough-order-of-magnitude (ROM) cost estimates of major components of the infrastructure necessary to be in place when carbon and nuclear energy sources are to be banned. The basic technology itself is not unfamiliar. 
The first electric streetcar was placed in service in 1835 and in 1888 Richmond Virginia became the first major city to use electricity to power $100 \%$ of public transportation [11]. Underground coal mining has been done with tethered and battery-powered heavy equipment for more than half a century. The first commercially viable electric car was brought onto the market in 1890 and within a decade more than $1 / 3$ of all automobiles on the road were electric [12]. The wind turbine was patented in 1888 and the first wind-powered municipal power grid was established in Vermont in 1943 [13].

These technologies have continued to be developed over the decades, with rule-of-thumb unit costs widely-used used in feasibility studies in both the public and private sector, and by business executives in the early stages of contemplating market entry or exit where detailed cost analysis is not yet warranted. Rule-of-thumb costing is sufficient for purposes of this paper's rough sizing of the key elements of GND:

Eliminate fossil fuel and nuclear energy: 320 million Americans consume about 100 quadrillions BTU's of energy each year and roughly 6\% of that is produced by the wind turbines and solar panels which have been manufactured and installed over the past three decades [14]. If we assume $100 \%$ wind power to fill the gap for ease of estimation (in practice, a mix of more expensive solar would be employed), it would take an additional 1.6 million $5 \mathrm{MW}$ towers to generate that much power, each with 900 tons of materials ("900 Tons of material to build just 1 windmill”, 2015) and a cost of $\$ 10$ million to manufacture and install. Total cost: $\$ 16$ trillion.

Replace aviation with HSR: The last estimate of the recently abandoned project to construct 400 miles of HSR from Los Angeles to San Francisco worked out to $\$ 82$ million per mile [15]. For estimating purposes, we can use the Interstate high system's 46,876 miles to approximate the cost to connect the nation's 4000 airports, most of which are within a reasonable distance of an Interstate highway. Rolling stock to transport passengers can be guessed at two \$52 million trains per each of the 5000 airplanes that are in the air en route at any given time. Total cost: $\$ 4.4$ trillion

Electrify freight rail: There are 137,000 miles of route track [16] that will need to be converted at a cost of $\$ 12$ million per mile [17] and 31,000 diesel locomotives to be replaced with electric locomotives at $\$ 3.5$ million each. Total cost: $\$ 1.7$ trillion.

Replace internal combustion highway vehicles with electric: There are 250 million cars, trucks, buses, and motorcycles and 1.6 million gas pumps [18] which will need to be replaced with electric vehicles and curb-side fast-charging stations which cost $\$ 60 \mathrm{k}$ each. For rough estimations, we can use an average of $\$ 100 \mathrm{k}$ per vehicle. Total cost: $\$ 25.2$ trillion.

Replace agricultural machinery with electric: There are 2.1 million farms in our country [19] which produce enough food and industrial stock (ethanol, cotton) to feed the nation and parts of the rest of the world. A trip to a modern farm will reveal a range of diesel equipment-tractors, combines, corn pickers, 
harvesters, backhoes, skid-steers, haul trucks. For estimating purposes, we can use $\$ 1 \mathrm{~mm}$ average per farm to be replaced with battery-powered electric equivalents and charging stations. Total cost: $\$ 2.1$ trillion.

Replace off-road construction machinery with electric: Data on the numbers of heavy equipment-cranes, bulldozers, graders, timber-harvesting machinery, mining machinery, etc. in current use is fragmented along the lines of its sector application and estimating each sector's capital stock is beyond the scope of this paper. For ROM cost, it assumes a similar effort to the agriculture sector: Total cost $\$ 2.1$ trillion.

That brings the ROM estimates of total industrial output for just these six GND bullet points to $\$ 51$ trillion. A crude estimate for the required additional new capital base-i.e. facilities and equipment in which to build these things-can be established based on a slightly adjusted 1:4 ratio of fixed capital to annual output [20] which adds another $\$ 1$ trillion to bring the working number of $\$ 52$ trillion as the minimum GND mobilization cost for purposes of argument.

\section{Expansion of the Industrial Base}

With due respect to the economics department at Boston University and its most famous Congressional alumnus, we don't "just pay for it", we pay somebody to do it. The "it" of GND is the $\$ 52$ trillion in durable goods and the facilities to produce them, and the "somebodies" are tens of millions of people working in tens of thousands of private sector firms to meet the GND the goal of a carbon-less economy.

Meeting the proposed GND deadline of 2030 will certainly not happen, but it is likely that Climate Science is not so specific on the exact date of the tipping point as to give up on the question of feasibility altogether.

To put $\$ 52$ trillion into context, consider that the current US industrial capacity is around \$2.4 Trillion. So if we stopped making every other single thing and converted every square foot of manufacturing space and every hour of manufacturing labor to GND infrastructure it would take 21 years to produce that amount of goods. We cannot live without the goods currently manufactured for 21 years, so that is not a realistic alternative.

If the millennials follow the lead of their great-grandparents and commit 50\% of industrial capacity to mobilization [4] it would stretch out to 42 years, well beyond the deadline for avoiding planetary extinction-and no one is likely to volunteer for 42 years of rationing and 70 hour weeks in the factories, mines, and mills no matter how noble the cause. And so we must immediately create significant new additional industrial capacity in order to reduce the GND mobilization duration.

To accomplish their mission in ten years, the deadline established by GND, we would need to triple the current existing industrial infrastructure-i.e. building 18 more of the 9 currently operating integrated steel mills and 150 new factories to manufacture wind turbine components, etc. New construction at this pace would invite catastrophe-too many novice equipment operators and not enough engineers and industrial architects to ensure safe construction. 
But extending the GND horizon to 20 years would lower the required replication to a $100 \%$ increase in capacity and output in the industrial sector, a daunting but not impossible task, given that existing facility and equipment designs are modular and for the most part stored in digital models that could be replicated quickly. For example, while we may not yet have designed battery-powered tractors and combines, factories that produce tractors and combines currently exist, as do factories that produce essential component systems-electric motors, batteries, chargers, actuators, control systems, etc. We will need to construct several more of each of those factories, and construction could begin immediately from the existing facility specifications and digital construction databases (drawings, $3 \mathrm{~d}$ models, CAD/CAM files, etc.) so they are ready to produce the new "green" capital goods as they are designed.

Tens of thousands of new production and logistics support facilities will need to be constructed and outfitted with the equipment to use them productively-overhead cranes, forklifts, machinery, computers, tools, robots, test equipment, etc. And many dozens of new mines and quarries will need to be opened to produce the necessary amounts of iron, copper, tin, lead, aggregates, and other industrial minerals used to make the machinery of GND. The value chains of the 20th American industrial era need not be re-invented, they can be replicated; we know the best strategic locations and logistics pathways from past experience-the Great Lakes have not moved, the navigable rivers have not changed course, the minerals in the ground are still in the same ground.

While the scope is challenging, it is not unprecedented; China accomplished a much larger proportional industrial expansion over a 20-year period around the turn of the century. It took the WWII generation only three years to reach peak monthly industrial output of similar proportional scale while millions were simultaneously enlisted into military service, diverted from the task of mobilization. For purposes of the next discussion of human capital repurposing, a 20 -year horizon and a $100 \%$ increase in industrial capacity is a serviceable debating framework. To meet a 20 -year goal, roughly $150 \%$ increase in industrial sector employment would be required to accommodate training, learning curve, and parallel development and production activities-surge period during which the facility infrastructure and capital goods infrastructure is simultaneously developed.

\section{Human Capital Needed for GND Mobilization}

There are 16 million people working in the manufacturing sector today [21] and a $150 \%$ increase would mean 24 million additional industrial jobs and people to fill them. 24 million is coincidentally the number who volunteered to join the industrial mobilization during WWII [4] and is a workable number for sake of argument. The GND total output is much higher than WWII adjusted for inflation, but current productivity is much higher also and will continue to increase rapidly as robotics and AI supplement human effort.

But any random 24 million bodies will not get the job done. In those wartime 
industrial factories of 1940,70\% of employees had above average IQ's of 100 and $30 \%$ were above 110 [9]. The industrial mobilization force was young-20 - 26 year-olds at the peak human speed of perception and absorption of new information and skill acquisition - and largely unemployed or not in the labor force.

Where can we find 24 million able-bodied young people of similar mental acuity not currently employed and motivated to volunteer into the immediate service of saving of the planet from extinction? We find them in post-secondary education and among the recent graduates of our colleges and universities. There are 19 million currently enrolled in college, 16 million of them millennials [22]. We cannot de-populate post-secondary completely; for starters, we will need the 769,000 current engineering students to complete their studies; they will have to design all this new stuff. In fact, we will probably need another million or so engineers of various types-mechanical engineers, electrical engineers, safety engineers, quality and test engineers, chemical engineers, civil engineers (mining and road building to place the wind towers), computer engineers. So many current students must remain in school but immediately switch majors.

And we will still need doctors and nurses and computer scientists and teachers and business majors-lots more business majors and MBAs to run the new industrial firms and facilities GND mobilization will create-along with retaining a right-sized (much smaller than current) cadre in all of the other degree fields. If we leave the absolutely necessary in school to supply the technical and management know-how required for GND mobilization and continue to meet minimum labor market requirements of all existing degrees, that will be roughly 7 million who remain in college and 12 million freed to immediately answer the call of GND duty.

A $65 \%$ reduction in students frees up $65 \%$ of the professors who teach them, too, so another million can be added to the mobilization pool. In the current post-secondary model only $20 \%$ of those teaching in colleges are tenured or tenure-track professors [23], and so the liberated would be adjuncts which the institutions have already deemed to be contingent workers with no permanent employment expectations.

Staff and administration employment in post-secondary has grown far faster than the growth in admissions, a surge justified by the additional resources required to support the new proportions of less-prepared students steadily added to student populations since the 1970 s. Only $28 \%$ of the $\$ 301$ billion currently spent annually on post-secondary is allocated to student instruction [24]. Reducing the student population back to roughly 1970's levels and reducing the number of degree options would, therefore, free up staff and administrative overhead by more than the $65 \%$ reduction in students, let's say $75 \%$ to be conservative. That adds another 1.5 million to the GND pool.

And thus, deconstructing post-secondary provides an immediately available GND mobilization pool of 12 million students, 1 million professors, and 1.5 million administrative staff who are passionately committed the cause and who can 
volunteer immediately to leave their posts and join the war on carbon. We can add in the 4 million currently unemployed and under-employed millennial college graduates [25] and increase the pool to 19 million. That is an impressive first step, although not quite a full complement of 24 million needed to implement GND with the urgency required.

But within a couple of years the millions new high school graduates who would have been diverted to college and stock the $65 \%$ of classrooms shuttered for GND mobilization will join the mobilization effort and create the force sufficient to support the 20 years of industrial mobilization for the GND-construct the new industrial base, build of the trains, vehicles, wind towers, rail, vehicles/chargers and other necessary goods, and install the national infrastructure to enable a total on ban fossil and nuclear energy.

Just as the industrial mobilization for WWI provides a precedent for GND mobilization, there is a past precedent for sector de-construction and re-construction on a scale even greater than is proposed for post-secondary. One example is the shift in national priorities that caused defense procurement to be cut by $70 \%$ in the 1990s, and the defense industrial base was right-sized to fit through repurposing and industry consolidation [26]. These things have been done before; we know how.

\section{GND Will Reindustrialize the US Economy}

The plight of current degree-holding (majority female) millennials is exemplified in its champion, Rep. Ocasio-Cortez, who despite holding a bachelors degree in international relations and economics from prestigious Boston University was still employed as a bartender and fast-food server several years after graduation. Those types of service sector jobs are rapidly being replaced with ordering kiosks and dispensing robots, and degreed millennials in those last-resort jobs will soon discover a new last resort-permanent unemployment. GND mobilization solves that problem.

When fully underway, GND mobilization will create an economic sector profile that resembles the US economy at the end of the 1960s [27], a decade of growth spurred by tax cuts at the start of the decade and a reduction in government spending at the end of it, along with milestone social progress throughout the passage of the Equal Pay Act of 1963 and Civil Rights Act of 1964 ending compensation discrimination by statute [28].

The proportion of US degree holders in 1970 was around 12\%. In 1970 manufacturing provided $23 \%$ of total employment in the economy, a proportion has fallen to approximately $8 \%$ today [29]. The GND mobilization economy will not only restore the 1970 industrial balance, but will surge to $40 \%$ employed in durable goods manufacturing, transportation, other manufacturing, construction, and agriculture, providing sufficient work for those current service sector workers whose jobs will soon be automated out of existence.

The surge in industrial output proposed in this paper to meet a 20 -year timeframe for GND realization will also reverse a half-century of growing income disparities and hollowing out of the middle class that has occurred due to sector 
shift away from industrial economic segments. All of the well-documented ill-effects of de-industrialization reverse when re-industrialization takes place. The current post-secondary model will not only be largely irrelevant in the reindustrialized GND economy, but it also presents the most significant impediment to GND implementation, sequestering the tens of millions of human capital needed to realize the goals and aspirations of GND as it is proposed. The misappropriation of human capital to post-secondary education is a barrier that must be removed if GND is to be realized.

\section{Occupational Matching at Scale}

The body of scholarship and documentation of psychometric testing methods utilized with such great success in the 1940s [4] is available today. The knowledge and tools necessary to facilitate repurposing of human resources on a massive scale need only to be dusted off and put to use again to optimize selection and retraining and specific occupational assignment in a mix that will provide the greatest likelihood of victory in the war on carbon.

Each wartime mobilization volunteer was put through a battery of tests of mental acuity, manual dexterity, and vocational aptitude. If 24 million people could be processed and matched to industrial occupations in a matter of months without the aid of computers in the 1940s, the task cannot take more than a few weeks today if we put our minds to it. And there is no reason to think that millennials are any less able to acquire completely alien vocational skill sets quickly than were previous generations of humans, given the right environment and method. Today's millennial infantryman enters the service as inexperienced in military science as his freshman cousin at university with sociology, but within a few months, he or she has mastered sophisticated weaponry, tactical deployment, and field communications while developing unit cohesion within a diverse team.

When it comes to mass mobilization, the military and industry are far more effective educators than their counterparts in post-secondary institutions. In the early 1940s, 8 million housewives and homemakers with no vocational experience whatsoever were transformed into highly-productive skilled contributors in a matter of weeks-immersion is a time-tested educational pedagogy. The tools to match aptitude with occupational billeting have existed for nearly a century-another wheel that does not invention.

\section{Repurposing Smart People}

College does not hold the exclusive franchise for education; critical thinking and problem-solving skills can just as readily be acquired in six years of industrial occupation as six years in a college classroom, probably faster and better. In fact, leading learning theorists have recently been pushing experiential learning pedagogies and project-based learning into post-secondary curricula [30].

Fluid intelligence cannot be taught; it is native. While IQ is not absolutely determinant in academic and career success, it is a major factor and it predicts the speed at which new information can be acquired and absorbed [31]. Speed of 
new learning is also essential to GND mobilization, just as it was for the World War II generation's mobilization success.

As was previously discussed, the proportions of Americans holding college degrees has grown significantly over the past four generations, from $4.6 \%$ in 1940 to $12 \%$ in 1970 to $20 \%$ in the early 1990 s to $35 \%$ today [8], with more than half of today's high-school graduates going on to post-secondary studies immediately [32]. As population proportions attending college have increased, the average intelligence of the degree-holding cohort has necessarily shifted downward.

By 1970 proportional standards, more than half of those attending college today would have qualified, and neither would more than half of the faculty teaching them. On the IQ bell curve, the top 4.6\% (1940 degreed population) sets at a nominal hurdle IQ of 125 , the top $12 \%$ (1970) sets at 120, the top 34\% (today) sets at 106 . The $62 \%$ of immediately enrolled HS graduates set the incoming bar at 92, below average. Those since those benchmarks would assume that everyone above the thresholds went to college-which is not the case-the actual hurdle rates for admission are several points lower.

The previously referenced 1940 factory Wonderlic distribution [9] document shows $80 \%$ of the WWII mobilization force posting scores higher than the 92 IQ equivalent of this appoximate hurdle rate for incoming college freshman. The factory floors of 1940 and the classrooms of 2019 are quite similar in terms of IQ distribution.

It is not apparent where any other not-working cohort of requisite size (24 million) and intellectual profile could be found to accomplish the goals of the Green New Deal; and it is even less apparent what purpose perpetuation of the current post-secondary model might serve that would be important than saving the planet from extinction.

\section{GND Mobilization Will Be an Upgrade for Millennials}

The argument could be made that Green New Deal is a New Better Deal for a majority of millennials being steered to college; one that provides six years of above-average earnings rather than six years of debt accumulation in the crucial early years, and a lifetime of higher earnings in the industrial sector versus perpetual underemployment as supply of degree holders vastly outstrips demand in service sector labor markets which will be increasingly automated.

It can be reasonably be expected that a proposal to deconstruct $2 / 3$ of post-secondary to facilitate GND mobilization will not be well-received by academics and administrators. For decades expansion of post-secondary has been predicated on two unquestioned tenets: 1) that a college degree is a pathway to increased earnings and higher purchasing power, and 2) that degree-enabled employment will provide higher levels of occupational satisfaction and engagement.

Both propositions are worthy of reconsideration. Millennials are the most highly college-educated generation in history, yet the least satisfied with their careers. A Gallup poll found $71 \%$ are not engaged at work, $84 \%$ are worried about 
financial security at retirement, and 56\% are stressed over finances [33]. In a recent survey, $66 \%$ of college graduates regret their decision to get their degree, $75 \%$ of those with degrees in the humanities [34]. Only half of students entering college will gaduate, and graduation rates for four-year degrees are now meausured at six years to reach that modest ratio [35].

And the higher earnings value of a bachelor degree is also no longer a given. The US Department of Education's National Center for Education Statistics collects and publishes data on college enrollments, graduation rates, with employment, and earnings by degree for 25 - 29-year-old graduates. Of the 32 degrees' average incomes for 24 - 29-year-olds, 16 show lower earnings than the average manufacturing hourly rate of $\$ 21.94$ [36]. Those lower-paying degrees and their variants account for the majority of students in post-secondary and are the fastest growing enrollments in this century [37].

- $57 \%$ increase in bachelors degrees since $2000 ; 87 \%$ increase in associates degrees;

- $94 \%$ increase in liberal arts and sciences, general studies, and humanities;

- only $8 \%$ increase in STEM field degrees degree fields with highest unemployment rates are liberal arts, general studies, and humanities.

Like its metaphorical inspiration, the World War II mobilization effort of the Greatest Generation, a reindustrialization of the United States economy to implement the GND would pay dividends for decades after the infrastructure necessary to eliminate carbon-based and nuclear energy sources have been installed. These new systems must be maintained and the capital equipment must be continuously replenished as it is used. The intellectual properties developed-patents, processes, trade secrets, etc, will propel increasing exports for generations as the rest of the world follows suit in replacing their own energy infrastructures to reduce emissions of greenhouse gasses.

\section{Conclusions}

The political question of whether or not to implement the Green New Deal is moot in the absence of any basis upon which to consider the feasibility of its possible implementation. Advocates for GND propose that the science of Climate Change is settled and that the apocalyptic consequences are beyond question, and this paper accepts those claims without examination, with the logical premise the assumption demands that GND implementation be the nation's top priority.

The paper has proposed a $\$ 52$ trillion rough-order-of-magnitude scope of the task of building and installing the requisite infrastructure to eliminate carbon and nuclear energy sources, and identified the only apparent available source of human capital with the requisite numbers and intellectual profile to accomplish it, along with the sector shift-from post-secondary education to industrial production-necessary to contemplate GND as a feasible national policy debate.

In constant 2018 dollars, the GND infrastructure creation will be roughly 26 
times more significant an undertaking at $\$ 52$ trillion than the $\$ 1.9$ trillion WWII mobilization of the 1940s. The US population is 3 times larger; the proposed duration for GND is 5 times longer; industrial productivity has tripled since 1940, and future technology-enabled productivity can be assumed to close the remaining gap. The industrial sector of the economy will surge to as high as $40 \%$ of GDP and provide decades of global competitive advantage as GND capital goods are developed for domestic investment and then exported to the world as the push for the elimination of carbon-based energy expands beyond the US borders.

It has offered a blueprint and a conceptual strategy, one that is certain to be less than warmly received in academic circles. But large-scale economic and social transformations throughout our history were not led from, nor embraced by, the academy. The "captains of industry" who brought America into the industrial age did not go to college-Rockefeller, Gould, Vanderbilt, Carnegie, Edison, and Ford. The icons of the digital age-Gates, Jobs, Dell, Ellison, and Zuckerberg-were all college drop-outs or more accurately opt-outs.

The victorious World War II mobilization was achieved by the spontaneous ordering of 600,000 private sector firms and 24 million young Americans who were repurposed to unfamiliar roles in industrial production. The proportion of the population holding college degrees in 1940 was $4.6 \%$. The full bell curve of human potential made themselves available for that effort and proved skeptics and scoffers, most notably the intelligentsia of the Axis powers, wrong.

Advocates of GND who draw inspiration from WWII mobilization will find that a nearly identical profile of available not-working human capital immediately available in sufficient numbers-24 million-and intellectual acuity exists today in the post-secondary education sector-students, faculty, and staff and its underemployed recent and future graduates.

Deconstruction and a $65 \%$ downsizing of the sector to 1970 proportions will preserve teaching and scholarship and ensure an adequate supply of professionals while liberating 16 million people for immediate GND duty. Repurposing millennial college graduates underemployed outside of their credentialed field raises an immediately available pool to 19 million. A few years of high school graduations entering the trades will bring the mobilization force up to the 24 million needed.

The increase in proportional college admissions since the 1970s correlates to the decline in the industrial base and the increasing proportion of the service sectors in the makeup of total GDP. It has been widely accepted that the decline of the industrial sector and shrinking of job prospects is a causal agent for the increase in college admissions, but we may have gotten that backward.

It could be that the systematic removal of the $100-125$ IQ participants from the blue-collar labor force and diversion to post-secondary education may have cut off the intellectual oxygen from the industrial sector, making it less globally competitive and agile. Misappropriation of intelligent human capital to college 
may have been the cause, not the consequence, of the decline and shrinkage of the industrial sector over the past four decades, a trend that has impacted minority employment and incomes especially hard [38] [39]. That would be a fruitful subject for additional research and theory building.

The incredible surge of industrial output of the wartime 1940s occurred in the absence of government regulation-one could argue it happened because of the absence of government regulation. American ingenuity was liberated and discovered, not commanded. For GND to have any hope of implementation, the onerous regulatory burdens placed on America's productive sectors in the post-war must be lifted and the regulatory state must be constrained for at least two decades while industrialists save the planet.

\section{Recommendations}

Accepting its advocates' premise that the alternative to Green New Deal implementation is planetary extinction, the paper proposes a broad outline of an urgent strategy upon which feasibility of GND on a 20-year timeline could be contemplated:

- $100 \%$ expansion of US industrial capacity;

- $\$ 52$ trillion in additional new industrial output over 20 years;

- $65 \%$ deconstruction and downsizing of US post-secondary education;

- repurposing post-secondary's excess occupants (24 million) to GND industrial mobilization force;

- utilization of established psychometric models to match aptitude with occupational placement aggressive de-regulation of the industrial, agriculture, and transportation sectors.

The limitations of a "white paper" such as this are well known to students, professors, and practitioners in the field of business management. Rough-orderof-magnitude cost estimates and rough-cut capacity analysis are gross macro-level tools employed to test the conceptual feasibility of proposed courses of action; they serve a "gating" purpose to rule out impractical ideas and move feasible ideas to the next phases of research and ideation that ultimately result in actionable plans upon which strategic decisions to move forward or not move forward can be reliably made.

The public policy question of whether or not to enact the Green New Deal cannot be intelligently approached without an appreciation of what will be required to accomplish it and consideration of who will make it happen. The paper relies on broad rules of thumb [40] [41] and proxies [42] that would need to be replaced with more in-depth study to determine a more accurate total cost of GND implementation and verification of timeline feasibility.

The debate over GND has thusfar focused on its end-state goals and impacts on global climate; the paper's blueprint and strategy outline suggest that the more significant public policy questions will revolve around the issues of US economic sector re-alignment and human capital repurposing that will be ne- 
cessary to achieve the desired GND end-state in a time frame sufficiently urgent to avoid the Climate Change apocalypse its advocates have predicted. The issues of feasibility and willingness of millennials to commit to a lifetime of industrial sector employment need to be incorporated into the public policy debate over the Green New Deal.

\section{Conflicts of Interest}

The author declares no conflicts of interest regarding the publication of this paper.

\section{References}

[1] (2019) Alexandria Ocasio-Cortez Calls Climate Change 'Our World War II'. https://reason.com/2019/01/22/alexandria-ocasio-cortez-calls-climate-c

[2] Wollershein, L. (2019) The 4 Most Dangerous Global Warming Deadlines and Tipping Points We Must NEVER Forget or, We Go Extinct.

https://www.joboneforhumanity.org/the_4_most_critical_global_warming_deadline s_and_tipping_point_we_must_never_forget

[3] Ackerman, J. (2019) The Vast Majority of Millennials Support a Green New Deal, No Shit.

http://millennialreview.org/2019/02/19/the-vast-majority-of-millennials-support-agreen-new-deal-no-shit/

[4] WWII: Mobilization.

https://history.army.mil/documents/mobpam.htm

[5] Aptitude-Test.Com (2019) The History of Psychometric Testing. https://aptitude-test.com/blog/articles/the-history-of-psychometric-testing/

[6] Jentz, T. (1996) Panzertruppen 2: The Complete Guide to the Creation \& Combat Employment of Germany's Tank Force 1943-1945. Schiffer Publishing, Ltd., Atglen, PA.

[7] Wonderlic Test History of the Wonderlic Test. https://wonderlictestsample.com/history-wonderlic-test/

[8] Clabaugh, J. (2017) If Education Counts, Americans Have Never Been Smarter. https://wtop.com/business-finance/2017/04/education-counts-americans-never-sma rter/

[9] (2015) Manpower Planning in an Industrial Firm (With Diagram). http://www.yourarticlelibrary.com/industries/manpower-planning-in-an-industrial -firm-with-diagram/46053/

[10] Brightest Green New Deal (GND) Resolution Full Text from AOC \& Sen. Markey. https://news.brightest.io/green-new-deal

[11] Bellis, M. (2016) Andrew Steele Hallidie and the First Cable Cars. https://www.thoughtco.com/history-of-streetcars-cable-cars-4075558

[12] Fuller, J. (2009) What Is the History of Electric Cars? https://auto.howstuffworks.com/fuel-efficiency/hybrid-technology/history-of-electri c-cars1.htm

[13] Richardson, J. (2014) America's First Wind Turbine Generated Electricity in 1888. https://cleantechnica.com/2014/06/22/americas-first-wind-turbine-generated-electri city- 1888 
[14] EIA U.S. Energy Information Administration (EIA)-Total Energy. https://www.eia.gov/totalenergy/

[15] Vartabedian, R. (2019) Costs for California's High-Speed Rail Project May Increase by $\$ 1.8$ Billion.

https://www.latimes.com/local/california/la-me-bullet-train-costs-20190430-story.h $\underline{\mathrm{tml}}$

[16] U.S. Railroad Track Miles \& Revenue by Year. https://www.railserve.com/stats_records/railroad_route_miles.htm

[17] Campos, J., de Rus, G. and Barron, I. (2007) The Cost of Building and Operating a New High Speed Rail Line. https://mpra.ub.uni-muenchen.de/12396/1/MPRA_paper_12396.pdf

[18] Fueleconomy (2004) How Many Gas Stations Are There in the U.S? https://www.fueleconomy.gov/feg/quizzes/answerQuiz16.shtml

[19] Infomory (2010) Number of Farms in the USA: A Knowledge Archive. https://infomory.com/numbers/number-of-farms-in-us/

[20] US Bureau of Economic Analysis Integrated Macroeconomic Accounts. https://apps.bea.gov/itable/itable.cfm?reqid=14\&step=1

[21] US Census Bureau, Center for Economic Studies Longitudinal Employer-Household Dynamics. https://lehd.ces.census.gov/data/pseo_beta_viz.htm

[22] NCES (2019) The Condition of Education, Postsecondary Education, Postsecondary Students, Immediate College Enrollment Rate. https://nces.ed.gov/programs/coe/indicator_cpa.asp

[23] Espinoza, L. Race and Ethnicity in Higher Education: A Status Report. http://1xfsu31b52d33idlp13twtos-wpengine.netdna-ssl.com/wp-content/uploads/20 19/02/REHE-Chapter-10-SA.pdf

[24] NCES Total Expenditures of Public Degree-Granting Postsecondary Institutions, by Purpose and Level of Institution: 2009-10 through 2015-16. https://nces.ed.gov/programs/digest/d17/tables/dt17_334.10.asp

[25] Freudenthal, C. (2016) Underemployed College Graduates Still a National Crisis. https://ourfuture.org/20160525/underemployed-college-graduates-still-a-national-c $\underline{\text { risis }}$

[26] Nerenz, T. (2006) Federal Government Procurement Policy Analysis: Has Extent and Effect of Contract Bundling on Small Business Been Overstated? Doctoral Dissertation, Northcentral University, San Diego, CA.

[27] Thompson, D. (2013) Corporate Profits Are Eating the Economy. https://www.theatlantic.com/business/archive/2013/03/corporate-profits-are-eating -the-economy/273687/

[28] US Economy 1960-1970. https://www.preceden.com/timelines/169533-us-economy-1960-1970

[29] Baily, M. and Bosworth, B. (2014) US Manufacturing: Understanding Its Past and Future Potential. Journal of Economic Perspectives, 28, 3-26.

https://doi.org/10.1257/jep.28.1.3

https://www.brookings.edu/wp-content/uploads/2016/06/us-manufacturing-past-an d-potential-future-baily-bosworth.pdf

[30] University of Maryland University College Enhancing the Learning Model. https://engage.umuc.edu/community/elm

[31] Academic Capital (2013) Book Review: The Gifted Adult-by Dr. Mary-Elain Jacob- 
son.

http://www.academic-capital.net/2013/07/book-review-gifted-adult-by-dr-mary.ht $\underline{\mathrm{ml}}$

[32] The Condition of Education (2019) Immediate College Enrollment Rate: Indicator February. https://nces.ed.gov/programs/coe/indicator_cpa.asp

[33] Delventhal, S. (2015) Measuring Job Satisfaction in the Millennial Age? Retrieved from

https://www.investopedia.com/articles/investing/091515/measuring-job-satisfaction -millennial-age.asp

[34] Min, S. (2019) Two Thirds of American Employees Regret Their College Degree. https://www.cbsnews.com/news/two-thirds-of-american-employees-regret-their-col lege-degrees/

[35] NBC News (2015) Just Over Half of All College Students Actually Graduate, Report Finds.

https://www.nbcnews.com/feature/freshman-year/just-over-half-all-college-student s-actually-graduate-report-finds-n465606

[36] NCES (2018) The Condition of Education-Population Characteristics and Economic Outcomes. Economic Outcomes, Employment Outcomes of Bachelor's Degree Recipients: Indicator May. https://nces.ed.gov/programs/coe/indicator_sbc.asp

[37] NCES Fast Facts: Most Popular Majors. https://nces.ed.gov/fastfacts/display.asp?id=37

[38] Household Data Annual Averages Employed Persons by Detailed Industry, Sex, Race, and Hispanic or Latino Ethnicity. https://www.bls.gov/cps/cpsaat18.pdf

[39] US Bureau of Labor Statistics (2019) Employment by Major Industry Sector. https://www.bls.gov/emp/tables/employment-by-major-industry-sector.htm

[40] Energyskeptic (2015) 900 Tons of Material to Build Just 1 Windmill. http://energyskeptic.com/2015/900-tons-of-material-to-build-just-1-windmill/

[41] How Much Does a Mile of Track Cost? http://cs.trains.com/trn/f/111/t/5093.aspx

[42] (2015) How Many Miles of Interstate Highways Are Here in the United States? https://www.reference.com/geography/many-miles-interstate-highways-united-stat es-23730dc91931b4ed 